instance by removing some shoots at various growing stages (level b of analysis). In this way, total biomass can be reduced and shoots will differ in age.

A differentiation in time and space of the developement phase may be so achieved. The smaller coppices, with an area less than about 10 ha, may need continuous supervision.

\title{
References
}

Bormann. F. H. \& G. E. Likens, 1979. Pattern and process in a forested ecosystem. Springer, New York. $253 \mathrm{pp}$

Hallé. F., R. A. A. Oldeman \& P. B. Tomlinson, 1978. Tropical trees and forests: an architectural analysis. Sprinter. Heidelberg. 441 pp.

This synopsis is based on an $M$. Sc. thesis entitled 'Geschiedenis, biomassa en structuur van enige elzenbossen, wilgen-, gagel-en kruipwilgstruwelen in Drenthe'. Department of Silviculture, Agricultural University, Wageningen, 1984. 136 pp., 40 figs., 6 tables, 37 refs., 4 appendices. Dutch.

Available as photocopies (order R017P, $f 40$ including postage) or microfiches (order R017M, f 17.50 including postage) at: NARD, clo Pudoc, P.O. Box 4, Wageningen, Netherlands (telex 45015 blhwg $\mathrm{hl}$ ).

\section{A matrix model of uneven-aged forest stands}

H. Rottier (Department of Forest Management, Agricultural University, P.O. Box 342, $6700 \mathrm{AH}$ Wageningen, Netherlands)

Received 25 June 1984; accepted 20 July 1984

Abstract. Matrix algebra showed that with uneven-aged stands allowable cut in a size class can be calculated from guessed number fractions of trees cut. The procedure can be used for calculation when optimization is impossible or not necessary. Key-words: Leslie matrix, uneven-aged stand, selective forest management, allowable cut.

Introduction. Forest in the Netherlands is sometimes managed on a small scale. The need arose to calculate allowable cut on a basis other than area. In the past attention has been concentrated on the ideal Liocourt curve (Knuchel, 1950; Meijer, 1980). Prodan (1949) indicated that the ideal curve depended on the cut. This idea is here developed into a general matrix model. 
Theory. Leslie matrices can be fitted for forestry as follows (e.g. Usher, 1969):

$$
n(t)_{i}=b_{i, i-1} \cdot n_{i-1}+a_{i i} \cdot n_{i}
$$

in which $n(t)_{i}$ is number of trees in diameter class $i$ at the end of period $t, b_{i, i-1}$ is number fraction of trees advancing one diameter class in period $t, a_{i i}$ is number fraction of trees staying in its diameter class in period $t, n_{i}$ and $n_{i-1}$ is number of trees in classes $i$ and $i-1$ at the beginning of period $t$.

For $m$ diameter classes, Equation 1 can be transformed into the matrix equation:

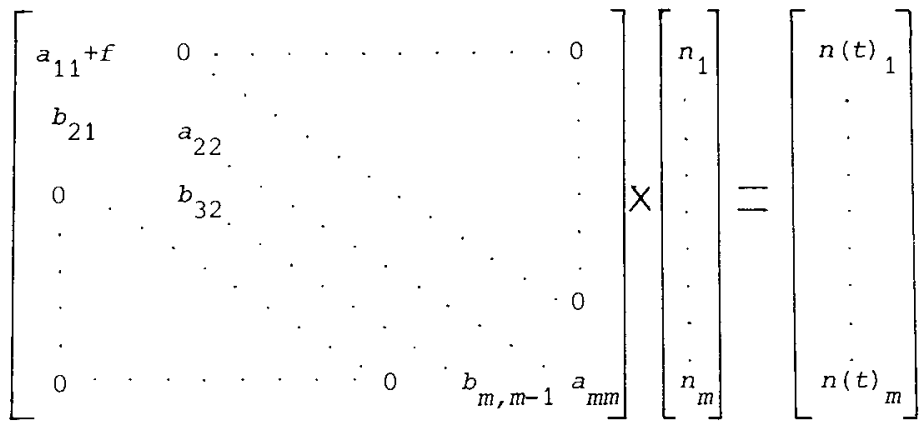

in which $f$ is ingrowth (number fraction of young trees entering the lowest diameter class),

$$
a_{i i}+b_{i+1, i} \leqslant 1 \text { (because a tree may die), }
$$

and

$$
1>a_{i i} \geqslant 0 ; \quad 1 \geqslant b_{i+1, i}>0 ; \quad f \geqslant 0
$$

This model can be extended with factors $c_{i+2} ; d_{i+3} \ldots$ for trees advancing more than one diameter class. However for simplicity they are not included in the equations, as this does not alter the theory nor the conclusions.

Equation 2 can be written as:

$$
T \cdot n=n(t)
$$

As $T$ (the transformation matrix) is a non-negative matrix, there is a latent root which has a non-negative latent vector. So:

$$
T \cdot n=\lambda \cdot n
$$

For a managed forest, the matrix model can be constructed as

$$
\begin{aligned}
& T \cdot(n-h)=\lambda \cdot n, \quad \text { or } \\
& T \cdot(I-H) \cdot n=\lambda \cdot n
\end{aligned}
$$




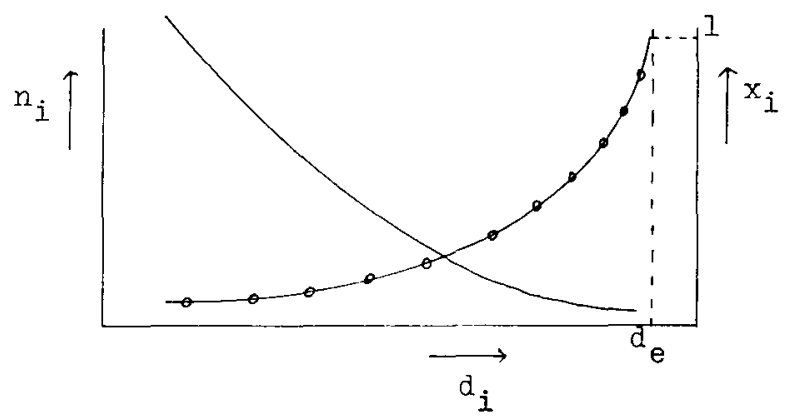

Fig. 1. Relation between numbers of trees $\left(n_{i}\right)$, number fractions of trees cut within a size class $\left(x_{i i}\right)$ and diameter $\left(d_{i}\right)$. - relation between $n_{i}$ and $d_{i} ; \bigcirc-0$, relation between $x_{i i}$ and $d_{i} ; d_{e}$, the management goal on diameter size.

In which $h$ is the $m \times 1$ matrix which contains the number of trees extracted. $I$ is the $m \times m$ unit matrix and $H$ is an $m \times m$ matrix with the number fractions cut in a size class, $x_{i i}\left(=h_{i} / n_{i}\right)$, on its diagonal and all other postions zero.

For $\lambda$, there are three biologically relevant cases:

1) $\lambda>1$

2) $\lambda=1$

3) $0<\lambda<1$

Cases 1 and 3 imply either exponential growth or the disappearance of the forest. As this is rarely true, we can state that the transformation matrix of a forest (whether managed or not) will change through all kinds of processes so that the laten root $\lambda$ will become 1 .

Discussion. Although matrix models have been used in forestry to calculate the stable distribution under a certain management (Usher, 1969; Satyamurthi, 1980; Buongiorno \& Michie, 1980), no attention has been paid to the change in the number fractions $\mathrm{a}, \mathrm{b}$ and $\mathrm{f}$. Calculation of these changes is difficult (e.g. Ek \& Monserud, 1979) and needs further research. It may be useful, however, to say something about the allowable cut without knowing these changes.

If we accept Equation 6 and the arguments about $\lambda$, the distribution will become stable for any reasonable matrix $H$. 'Reasonable' in this context means in accord to Fig. 1 (after Roches, 1970).

With this approach planning can be justified without knowing the exact value of the parameters.

\section{References}

Buongiorno, J. \& B. R. Michie, 1980. A matrix model of uneven-aged forest management, Forest Science 26: $609-625$.

Ek, A. R. \& R. A. Monserud, 1979. Performance and comparison of stand growth models based on individual tree and diameter class growth. Canadian Journal of Forest Research 9: 231-244.

Knuchel, H., 1950. Planung und Kontrolle im Forstbetrieb. Verlag H. R. Sauerländer \& Co, Aurau. $337 \mathrm{pp}$. 
Meijer, J., 1980. Constructie van een ideaalcurve met gebruikmaking van de lognormale verdeling. M.Sc. thesis, Wageningen. $13 \mathrm{pp}$.

Prodan, M., 1949. Die theoretische Bestimmung des Gleichgewichtszustandes im Plenterwalde Schweizerische Zeitschrift für das Forstwesen 100: 81-98.

Roches, D., 1970 Etude comparative des prix de revient d'une récolte en forêt regulière et en forêst jardinée. Schweizerische Zeitschrift für das Forstwesen 121: 215-227.

Satyamurthi. K. R., 1980. Sylvometrics. Indian Forest Record (new series) 2(2).

Usher, M. B., 1969. A matrix model for forest management. Biometrics 25: 309-315.

This synopsis is based on an M. Sc. thesis entitled 'Theorie t.a.v. kap bij kleinschalig bosbeheer', Department of Forest Management, Agricultural University, Wageningen, 1983.44 pp., 5 figs., 4 tables, 30 refs., appendix. Dutch.

Available as paper copy (order R018P, $f 20$ including postage) or microfiche (order R018M, f 12.50 including postage) at: NARD, clo Pudoc, P.O. Box 4, 6700 AA Wageningen, Netherlands (telex 45015 blhwg nl).

\section{Effect of muscle temperature soon after slaughter on pork quality: a pilot study}

P. G. van der Wal and G. Eikelenboom (Research Insitute for Animal Production 'Schoonoord', P.O. Box 501, 3700 AM Zeist, Netherlands)

Received 9 July 1984; accepted 3 August 1984

Abstract. The effect of various environmental temperatures, ranging between 42.5 and $25^{\circ} \mathrm{C}$ during the first $2 \mathrm{~h}$ after slaughter, on pork quality was studied in longissimus dorsi samples. Higher environmental temperatures resulted in higher lactate and lower $\mathrm{pH} 2 \mathrm{~h}$ after slaughter. Samples kept at higher environmental temperatures $\left(42.5\right.$ and $40^{\circ} \mathrm{C}$ ) showed characteristics typical for pale soft exudative pork.

Key-words: body temperature, environmental temperature, pork, pale soft exudative, drip loss, meat quality.

Introduction. Pale soft exudative pork is the result of rapid decline in $\mathrm{pH}$ after slaughter and elevated muscle temperature, which cause denaturation of muscular proteins. Heat production in porcine muscle is increased by stress, particularly in stress-susceptible pigs (Sybesma \& Eikelenboom, 1978). With present slaughter procedures, carcase temperature frequently remains high for the first hours after 